\title{
Involvement of Cell Cycle and Apoptosis-Related Protein p21 in Control of Secretory Activity of Porcine Ovarian Cells
}

\author{
Silvia Pavlová ${ }^{1 *}$, Dušan Vašíček ${ }^{2}$, Ján Kotwica ${ }^{3}$ and Alexander V. Sirotkin ${ }^{1,2}$ \\ ${ }^{1}$ Department of Zoology \& Anthropology, Faculty of Natural Sciences, Constantine The Philosopher University in Nitra, 94974 Nitra, Slovakia \\ ${ }^{2}$ Research Centre of Animal Production, Hlohovecká 2, 949 92, Nitra, Slovakia
}

${ }^{3}$ Institute of Animal Reproductio and Food Research, 10-718 Olsztyn-Kortowo, Poland

\begin{abstract}
Protein p21, member of the Cip/Kip family of cyclin kinase inhibitors, is a physiological regulator of cell cycle, differentiation and apoptosis in various cell types. Its role in regulation of secretory activity of both non-ovarian and ovarian tissues is unknown.

The aim of our in-vitro experiments was to examine possible involvement of p21 in regulation of porcine ovarian granulosa cells secretory activity. Monolayer of primary granulosa cells was transfected with plasmid vector encoding human p21 cDNA, and cultured with or without addition of follicle-stimulating hormone $(\mathrm{FSH})$ or insulin-like growth factor I (IGF-I) (both at $0,1,10$ or $100 \mathrm{ng} / \mathrm{ml})$. Release of IGF-I, progesterone $\left(P_{4}\right)$, oxytocin $(\mathrm{OT})$, prostaglandins $\mathrm{E}_{2}\left(\mathrm{PGE}_{2}\right)$ and $F_{2 a}\left(P F_{2 a}\right)$ was assayed by using RIA. We observed, that (1) p21 promoted the release of $P_{4}, O T, P G E_{2}$ and had

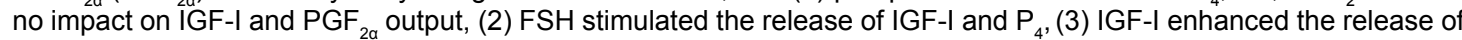
$\mathrm{OT}, \mathrm{P}_{4}$ and $\mathrm{PGE}_{2}$, but it inhibited the release of $\mathrm{PGF}_{2 a^{\prime}},(4)$ overexpression of 21 was able to modify the effects of IGF-I, but not of FSH.
\end{abstract}

Our observations (1) demonstrate for a first time the involvement of p21 in regulation of hormones release $P_{4}$ $\mathrm{OT}$ and $\mathrm{PGE}_{2}$ by ovarian granulosa cells, (2) confirm the regulation of porcine ovarian hormone release by $\mathrm{FSH}$ and IGF-I and (3) suggest, that p21 is not a mediator of FSH action on porcine ovarian $\mathrm{P}_{4}$ and IGF-I; involvement of p21 in mediating IGF-I action on some porcine ovarian hormones is not to be excluded, but it requires further confirmation.

Keywords: Porcine ovarian granulosa cells; p21; FSH; IGF-I; P; OT; $\mathrm{PGE}_{2} ; \mathrm{PGF}_{2 \alpha}$

\section{Introduction}

Protein p21 belongs to the Cip/Kip family of cyclin kinase inhibitors [1]. p21 is a physiological regulator of cell cycle [2-9] cell differentiation [10-14], apoptosis [15-17] and expression of IGF-I mRNA [14] in various non-ovarian tissues. The available knowledge concerning involvement of p21 in control of ovarian functions are limited by reports on presence of p21 protein in ovaries of mice $[18,19]$, macaca mulatta [20] and human [21-23] and on p21-induced suppression of proliferation of mice ovarian granulosa cells [19]. The role of p21 in regulation of secretory activity of both non-ovarian and ovarian tissues remains unknown yet.

In contrast to $\mathrm{p} 21$, the role of follicle stimulating hormone (FSH) and insulin-like growth factor I (IGF-I) in control of ovarian secretory activity is well documented [24-28]. IGF-I in non-ovarian cells can promote p21 accumulation $[17,29]$. Therefore, it is possible, that the action of IGF-I and maybe of other hormones on ovarian secretory activity could be mediated by p21. In this case, effects of p21 and hormone should be either similar or opposite, and changes in p21 should modify action of hormone. Nevertheless, the effect of p21 on ovarian secretory activity and on the action of FSH and IGF-I were not examined yet.

In our in vitro experiments we aimed to examine possible involvement of p21 in regulation of porcine ovarian granulosa cell secretory activity. For this purpose, we examined the influence of p21 overexpression on release of IGF-I, progesterone $\left(\mathrm{P}_{4}\right)$, oxytocin (OT), prostaglandin $\mathrm{E}_{2}\left(\mathrm{PGE}_{2}\right)$ and prostaglandin $\mathrm{F}_{2 \alpha}\left(\mathrm{PGF}_{2 \alpha}\right)$. The second aim of our studies was to detect, whether p21 might be involved in mediating actions of FSH and IGF-I on granulosa cells. For this purpose, we compared effects of p21 overexpression, FSH and IGF-I on release of hormones and examined the influence of transfectioninduced overexpression of p21 on response of granulosa cells to FSH and IGF-I.

\section{Materials and Methods}

\section{Preparation, culture and processing of ovarian cells}

Granulosa cells used in our in vitro experiments were obtained from the ovaries of non-cycling, pubertal (100-120 days of age) gilts, after a slaughter at a local abattoir. The stage of ovarian cycle was determined by visual inspection of both ovaries. Only ovaries containing medium size $(2-5 \mathrm{~mm}$ in diameter) follicles, but no ovulations and fresh or old corpora lutea were used in the experiments. The ovaries were transported to the laboratory in a sterile physiological solution at $4^{\circ} \mathrm{C}$. Granulosa cells were harvested and processed as described previously [30-32]. Briefly, the follicular fluid was aspirated from follicles of 3-5 $\mathrm{mm}$ in diameter and suspended in Dulbecco's modified Eagle's medium (DMEM)/F-12 1:1 + 2\% fetal calf serum (FCS) (all from Sigma, St. Louis, USA). The harvested cells were washed twice by centrifugation for $10 \mathrm{~min}$ at $200 \mathrm{xg}$. The pellet

*Corresponding author: Silvia Pavlová, Department of Zoology \& Anthropology, Faculty of Natural Sciences, Constantine The Philosopher University in Nitra, 94974 Nitra, Slovakia, Tel: +421-944 155 944; Fax: +421-45 673 8832; E-mail: pavlova.silvia@gmail.com

Received October 30, 2010; Accepted November 21, 2010; Published November 21, 2010

Citation: Pavlová S, Vašiček D, Kotwica J, Sirotkin AV (2010) Involvement of Cell Cycle and Apoptosis-Related Protein p21 in Control of Secretory Activity of Porcine Ovarian Cells. J Steroids Hormon Sci 1:102. doi:10.4172/2157-7536.1000102

Copyright: @ 2010 Pavlová S, et al. This is an open-access article distributed under the terms of the Creative Commons Attribution License, which permits unrestricted use, distribution, and reproduction in any medium, provided the original author and source are credited. 
Citation: Pavlová S, Vašíček D, Kotwica J, Sirotkin AV (2010) Involvement of Cell Cycle and Apoptosis-Related Protein p21 in Control of Secretory Activity of Porcine Ovarian Cells. J Steroids Hormon Sci 1:102. doi:10.4172/2157-7536.1000102

Page 2 of 5

of granulosa cells was resuspensed in DMEM/F-12 1:1 supplemented with $10 \%$ FCS and with $1 \%$ antibiotic-antimycotic solution (Sigma) to a concentration $10^{6}$ cells/ml medium. The portions of cells suspension were dispensed to 24-well culture plates (Becton Dickinson, Lincoln Park, NJ, USA) in $1 \mathrm{ml}$ aliquots. Cells were incubated at $37.5^{\circ} \mathrm{C}$ and $5 \%$ $\mathrm{CO}_{2}$ humidified air until a 50-60\% confluent monolayer was formed (18-24 hours). After primary cultivation, the medium from the plates was aspirated and cells were washed by DMEM/F12. Immediately, transfection medium containing a transfection reagent Roti Fect (Carl Roth, Karlsruhe, Germany) and a gene construct were added to the cell culture, according to the manufacturer's instructions. Cells were divided into three groups: the first, control group was transfected with tranfection reagent and a plasmid vector (pEGFP-N1, Clontech cat.no: 6085-1) encoding a reporter gene Enhanced Green Fluorescent Protein (EGFP) (GenBank accession: U55762). Second group was transfected with expression vector (WAF1-pcDNA3, gift from Dr. Perkins) for human p21 cDNA (GenBank acc.no: S67388.1) [33]. Granulosa cells were incubated after transfection in culture medium (DMEM/F-12 supplemented with $10 \%$ FCS and $1 \%$ antibioticantimycotic solution, $2 \mathrm{ml}$ medium per well) at $37.5^{\circ} \mathrm{C}$ and $5 \% \mathrm{CO}_{2}$ humidified air until the formation of approximately $80 \%$ confluent monolayer of adherent cells. Culture medium was supplemened with addition of porcine FSH or IGF-I (gift from Dr.A.P.F.Parlow, National Hormone and Pituitary Program, Torrance, CA, USA) at concentrations $0,1,10$ or $100 \mathrm{ng} / \mathrm{ml}$. At the time of finishing the culture, cell numbers and viability were determined by Trypan blue staining and counting in a haemocytometer. The viability of cells was $70-80 \%$. No statistically significant differences in these indices between control and experimental groups were observed. After terminating the culture, the medium from 24 well plates was aspirated and frozen at $-18^{\circ} \mathrm{C}$ to await RIA.

\section{Immunoassay}

Concentrations of IGF-I, OT, $\mathrm{P}_{4} \mathrm{PGE}_{2}$ and $\mathrm{PGF}_{2 \alpha}$ were determined in $25-100 \mu$ l samples of incubation medium by RIA. The concentrations of OT, PGE ${ }_{2}$ and $\mathrm{PGF}_{2 \alpha}$ were assayed using by our own RIA/IRMA systems [34]. The release of hormones IGF-I and $\mathrm{P}_{4}$ was assayed using RIA/IRMA kits from Immunotech (Marseille, France) according to the manufacturer's instructions. The characteristics of assays are described in Table 1.

\section{SDS-PAGE-Western immunoblotting}

SDS-PAGE-Western immunoblotting was performed as described previously [32] to evaluate effectivity of cell transfection with p21 cDNA gene construct. Primary mouse monoclonal antibodies against p21 (Santa Cruz Biotechnology) (dilution 1:250) and secondary polyclonal rabbit antibodies raised against mouse IgGs and labelled with horseradish peroxidase (Sevac, Prague, Czech Republic) (dilution 1:1000) were used. Immunoreactive bands were visualised using the detection reagents Upstate Visualizer Western Blot (Temecula, CA, USA) and exposed on ECL Hyper-film (Amersham International).

\section{Statistics}

Each experimental group was represented by 6 culture wells in plates. Each series of experiments was performed 3 times. Samples for each experiment were obtained from 30-35 animals. The data shown are the means of values of these three separate experiments.

RIA: Assays of hormone concentration in the incubation medium were performed in duplicates. The values of blank controls (serumsupplemented medium incubated without cells) were subtracted from the specific values determined by RIA in cell-conditioned medium to exclude any non-specific background (less than $10 \%$ of total values). Rates of secretion were calculated per $10^{6}$ viable cells/day.

SDS-PAGE: Samples from each corresponding group (6 per group) were pooled before the performing SDS-PAGE. Quantification of the specific signals was performed by using densitometry by using Kodak Molecular Imaging Software 4.0 (Eastman Kodak Company, Rochester, NY, USA).

Significant differences between the experiments and groups were evaluated using ANOVA for repeated measurements followed by paired Wilcoxon-Mann-Whitney test, Sigma Plot 11.0 software (Systat Software, GmbH, and Erkhart, Germany). Differences from control at $\mathrm{P}<0.05$ were considered as significant.

\section{Results}

Cultured porcine granulosa cells were able to create a monolayer in the culture, to produce protein p21 and to release hormones IGF-I, OT, $\mathrm{P}_{4}, \mathrm{PGE}_{2}$ and $\mathrm{PGF}_{2 \alpha}$.

Fluorescent microscopy showed, that more than $50 \%$ of cells which was transfected with a plasmid DNA vector with the reporter gene for EGFP, contained fluorescent EGFP. It indicated succesful transfection with marker reporter plasmid. Additionally, SDS-PAGEWestern immunoblotting demonstrated that cells transfected with p21 cDNA vector plasmid produced significantly higher amount of this protein as control cells (Figure 1).

RIA analysis showed, that p21 promoted $\mathrm{P}_{4}$ (Figure 2a,3b), OT (Figure 3a) and $\mathrm{PGE}_{2}$ (Figure 3c) release, but did not influenced IGF-I (Figure $2 \mathrm{~b}$ ) and $\mathrm{PGF}_{2 \alpha}$ release (Figure $3 \mathrm{~d}$ ).

In non-transfected cells, FSH, when added to the culture medium, increased the release of IGF-I (Figure $2 \mathrm{~b}$ ) and $\mathrm{P}_{4}$ (Figure 2a) at all used doses $(0,1,10,100 \mathrm{ng} / \mathrm{ml})$. IGF-I (at concentrations 10 and $100 \mathrm{ng} /$ $\mathrm{ml}$, but not at $1 \mathrm{ng} / \mathrm{ml}$ ) promoted the release of OT (Figure 3a) and $\mathrm{P}_{4}$ (Figure 3b). IGF-I (at concentration $100 \mathrm{ng} / \mathrm{ml}$ but not at 1 and $10 \mathrm{ng} /$ $\mathrm{ml}$ ) enhanced the release of $\mathrm{PGE}_{2}$ (Figure 3c) and (at all used doses) inhibited the release of $\mathrm{PGF}_{2 \alpha}$ (Figure 3d).

FSH added to culture medium of cells transfected with vector encoding p21 cDNA promoted the release of IGF-I (at doses 10 and $100 \mathrm{ng} / \mathrm{ml}$, but not at dose $1 \mathrm{ng} / \mathrm{ml}$; (Figure $2 \mathrm{~b}$ ) and $\mathrm{P}_{4}$ (at all used concentrations; Figure 2a). IGF-I in cells overexpressing p21 did not

\begin{tabular}{|c|c|c|c|c|}
\hline \multirow{2}{*}{$\begin{array}{l}\text { Substance } \\
\text { assayed }\end{array}$} & \multirow{2}{*}{ Specificity of assay (cross-reactivity of antiserum) } & \multirow{2}{*}{$\begin{array}{l}\text { Sensitivity of } \\
\text { assay }(\mathrm{ng} / \mathrm{ml})\end{array}$} & \multicolumn{2}{|c|}{ Coefficients of variation } \\
\hline & & & Intra-assay & Inter-assay \\
\hline IGF-I & $<0.001 \%$ to insulin, proinsulin, IGF-II, GH & 2.0 & $6.3 \%$ & $6.8 \%$ \\
\hline Oxytocin & $<0.01 \%$ to arginine-vasopressin, lysine. -vasopressin, arginine-vasotocin, ghrelin, leptin and FSH & 0.12 & 13. 1 & 8. 0 \\
\hline Progesterone & $<0.01 \%$ cortisol, estradiol, $5 \alpha-, 5 \beta$-Pregnandione, $16 \alpha-, 17 \alpha-, 6 \beta$-Hydroxyprogesterone & 0.05 & $5.8 \%$ & $9.0 \%$ \\
\hline $\mathrm{PGE}_{2}$ & $\begin{array}{l}<28.0 \% \text { to PGA-1, }<7.0 \% \text { to PGA-2, }<0.6 \% \text { to PGB-1, }<1.4 \% \text { to PGB-2, }<5.0 \% \text { to PGF-1, }<1.5 \% \text { to PGF- } \\
2,165 \% \text { to PGE- } 1,100 \% \text { to PGE-2 }\end{array}$ & 0.015 & 7.5 & 4. 0 \\
\hline $\mathrm{PGF}_{2 \alpha}$ & $<0.01 \%$ to PGA-1, PGA-2, PGB-1, PGB-2, $<0.1 \%$ to PGE-1, PGE-2, $66 \%$ to PGF-1, $100 \%$ to PGF-2 & 0.003 & 10.5 & 5.6 \\
\hline
\end{tabular}

Table 1. Characteristics of immunoassays used in experiments. 


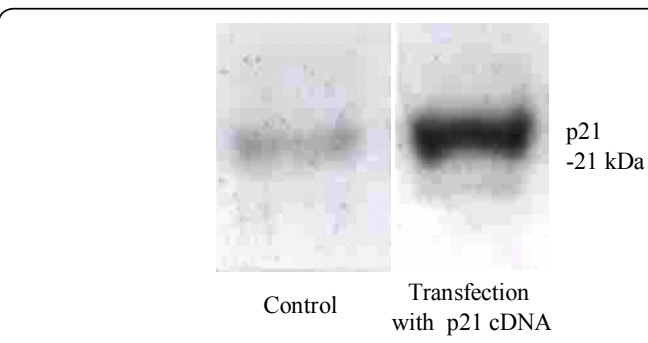

Figure 1: Effect of transfection with human p21 cDNA on the accumulation of porcine granulosa cells containig protein p21. Monolayer of granulosa cells of prepubertal gilts were transfected with p21 gene construct and after 30 hours of incubation analyzed by SDS-PAGE-Western immunoblotting. Molecular weight is indicated $(\mathrm{kDa})$. Loading control GAPDH is not shown.

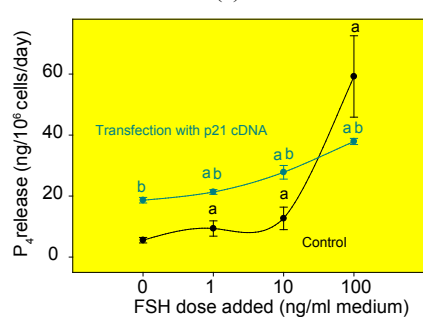

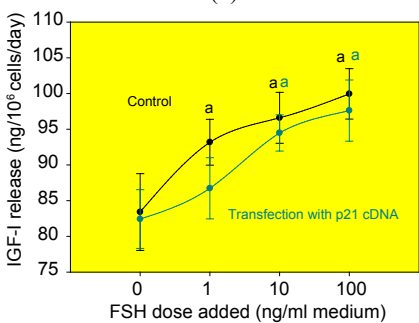

Figure 2: Effect of FSH $(0,1,10,100 \mathrm{ng} / \mathrm{ml})$ and transfection with human $\mathrm{p} 21$ cDNA on the release of $\mathrm{P}_{4}(\mathbf{a})$ and IGF-I (b) Monolayer of granulosa cells of prepubertal gilts were transfected with human p21 or EGFP gene construct (as control) and after 30 hours of incubation with or without FSH $(0,1,10,100 \mathrm{ng}$ $\mathrm{ml}$ medium) analyzed by RIA. Data are the mean +- S.E.M. a - Effect of FSH addition: significant $(P<0.05)$ differences between cells cultured with $(1,10$ or $100 \mathrm{ng} / \mathrm{ml})$ and without $(0 \mathrm{ng} / \mathrm{ml}) \mathrm{FSH} . \mathrm{b}$ - Effect of transfection with $\mathrm{p} 21$ gene construct: significant differences between corresponding groups of cells transfected and not transfected with p21 cDNA construct.

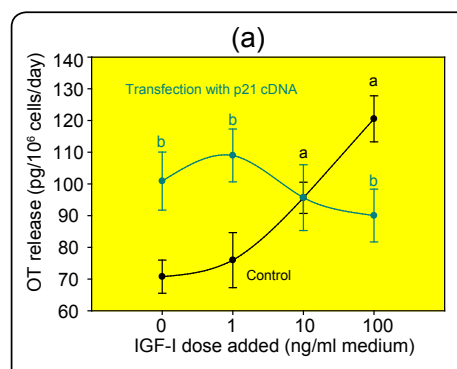

(c)
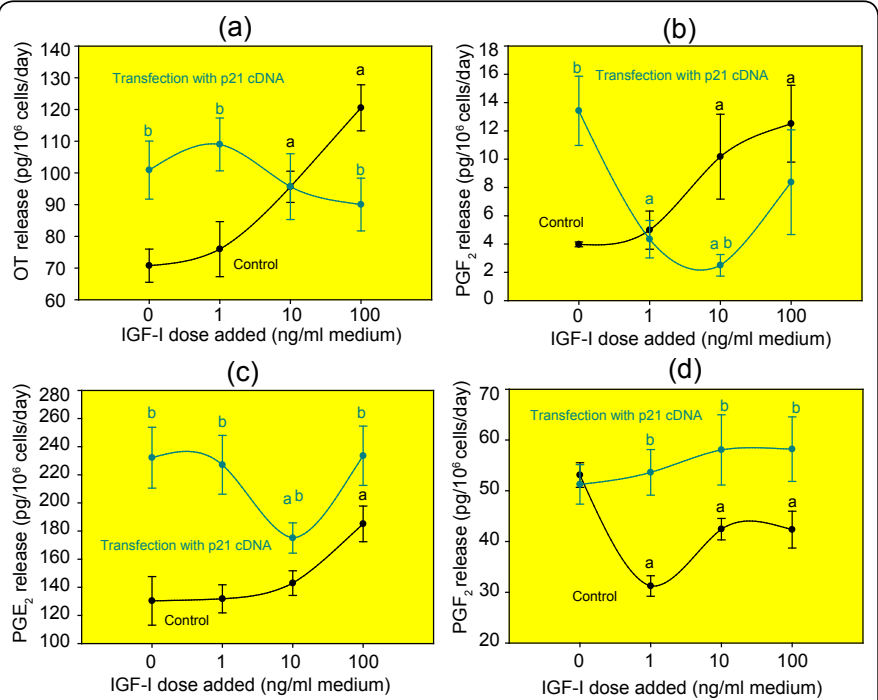

(d)

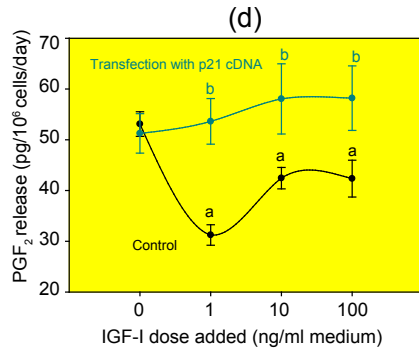

Figure 3: Effect of FSH $(0,1,10,100 \mathrm{ng} / \mathrm{ml})$ and transfection with human p2 cDNA on the release of $\mathrm{P}_{4}(\mathbf{a})$ and IGF-I (b) Monolayer of granulosa cells of prepubertal gilts were transfected with human p21 or EGFP gene construct (as control) and after 30 hours of incubation with or without FSH $(0,1,10,100 \mathrm{ng} /$ $\mathrm{ml}$ medium) analyzed by RIA. Data are the mean +- S.E.M. a - Effect of FSH addition: significant $(P<0.05)$ differences between cells cultured with $(1,10$ or $100 \mathrm{ng} / \mathrm{ml})$ and without $(0 \mathrm{ng} / \mathrm{ml}) \mathrm{FSH}$. b - Effect of transfection with p21 gene construct: significant differences between corresponding groups of cells transfected and not transfected with p21 cDNA construct. influence OT (Figure 3a) and $\mathrm{PGF}_{2 \alpha}$ (Figure 3d) release. In these cells, IGF-I (at dose 1 and $10 \mathrm{ng} / \mathrm{ml}$, but not at $100 \mathrm{ng} / \mathrm{ml}$ ) inhibited $\mathrm{P}_{4}$ release (Figure $3 \mathrm{~b}$ ) and (at $10 \mathrm{ng} / \mathrm{ml}$, but not at 1 or $100 \mathrm{ng} / \mathrm{ml}$ ) reduced the $\mathrm{PGE}_{2}$ output (Figure 3c).

\section{Discussion}

Our observations of release of hormones by cultured porcine granulosa cells correspond with previous data on secretion of IGF-I [35], $\mathrm{P}_{4}$ [36], OT [37], $\mathrm{PGE}_{2}, \mathrm{PGF}_{2 \alpha}$ by porcine granulosa cells.

\section{Effect of p21 on secretory activity of porcine granulosa cells}

Our observations of protein p21 presence in porcine ovarian granulosa cells are the first demonstrations of production of this protein in porcine ovary. Moreover, this is the first demonstration of involvement of p21 in control of hormones secretion. In our experiments, p21 stimulated $\mathrm{P}_{4}$, OT and $\mathrm{PGE}_{2}$ release but did not affect IGF-I and $\mathrm{PGF}_{2 \alpha}$ release. As $\mathrm{P}_{4}$ is inhibitor of granulosa cell cycle [38] and p21 enhanced its release, it is possible, that p21 is able to regulate granulosa cell cycle through up-regulation of $\mathrm{P}_{4}$ output as well. $\mathrm{P}_{4}, \mathrm{PGE}_{2}$ and $\mathrm{OT}$ are important luteotropic factors [39-45]. It is therefore not to be excluded, that $\mathrm{p} 21$ could promote differentiation/ luteinisation of granulosa cells through the stimulatory effect on $\mathrm{P}_{4}$, OT and PGE 2 release. On the other hand, p21 is not probably involved in prostaglandin $\mathrm{F}_{2 \alpha}$-induced luteolysis as it did not affect the release of luteolytic PGF $F_{2 \alpha}$. Our observations, that p21 did not effect IGF-I release are not in line with report of [14], who documented stimulatory action of p21 on IGF-I expression in non-ovarian cells. It suggests, that p21 action on IGF-I can be tissue-specific.

\section{Effects of FSH and IGF-I on secretory activity of porcine granulosa cells}

In our experiments FSH promoted the release of hormones IGF-I and $\mathrm{P}_{4}$ These observations correspond the known data on stimulatory effect of gonadotropin on secretion of IGF-I $[35,26]$ and $\mathrm{P}_{4}[36,45]$ by cultured porcine granulosa cells. IGF-I increased the release of OT, $\mathrm{P}_{4}$ and $\mathrm{PGE}_{2}$ and inhibited the release of $\mathrm{PGF}_{2 \alpha}$. Our data on stimulatory action of IGF-I on OT release and on inhibitory effect on $\mathrm{PGF}_{2 \alpha}$ release correspond previous reports of [46] (bovine granulosa cells), of $[37,47]$ (bovine and porcine granulosa cells) and of [48] (human corpus luteum). The observed activation of $\mathrm{P}_{4}$ release after IGF-I additions are in line with previous reports of [24] (rat, porcine and human granulosa cells), of [49] (rabit granulosa cells), of [50] (porcine corpus luteum). Concerning regulation of $\mathrm{PGE}_{2}$ secretion by IGF-I, [48] observed stimulatory effect of IGF-I on PGE release in human corpus luteum, [27] documented up-regulation of $\mathrm{PGE}_{2}$ synthesis in transformed human ovarian cells, [37] did not observe any effect of IGF-I on PGE 2 secretion by porcine granulosa cells. In our studies IGF-I stimulated PGE 2 release, which correspond the majority of publications mentioned above. In summary, our results confirm the importance of IGF-I in regulation of secretory activity of ovarian granulosa cells.

\section{Interrelationskips between p21, FSH and IGF-I in porcine granulosa cells}

In Introduction it was hypothesised, that p21 could be a mediator of FSH and/or IGF-I actions on secretory activity of granulosa cells. We postulated, that if these hormones regulate ovarian secretory activity through stimulation of p21, they and p21 should have similar effects, and overexpression of p21 should promote effects of hormones. On the contrary, we postulated that if FSH and IGF-I affect 
Citation: Pavlová S, Vašíček D, Kotwica J, Sirotkin AV (2010) Involvement of Cell Cycle and Apoptosis-Related Protein p21 in Control of Secretory Activity of Porcine Ovarian Cells. J Steroids Hormon Sci 1:102. doi:10.4172/2157-7536.1000102

ovary through inhibition of $\mathrm{p} 21$, their effects should be opposite, and overexpression of p21 should prevent or invert the effects of FSH and IGF-I.

In our experiments FSH stimulated the release of IGF-I and $\mathrm{P}_{4}$ and p21 did not affect IGF-I release and promoted $\mathrm{P}_{4}$ output. Therefore, only part of FSH and p21 effects were similar. Furthermore, p21 did not promote or prevent FSH action. These observations did not confirm the hypothesis about mediating FSH action by p21 on IGF-I and $\mathrm{P}_{4}$ release by porcine granulosa cells.

IGF-I and overexpression of p21 had similar stimulatory actions on the release of $\mathrm{P}_{4}, \mathrm{OT}$ and $\mathrm{PGE}_{2}$, but not on $\mathrm{PGF}_{2 \alpha}$. This indicates, that IGF-I can affect $\mathrm{P}_{4}$, OT and $\mathrm{PGE}_{2}$ via stimulation of $\mathrm{p} 21$ accumulation. On the other hand, overexpression of $\mathrm{p} 21$ did not promote, but rather prevented IGF-I effects on release of ovarian hormones-blocked its actions on $\mathrm{OT}$ and $\mathrm{PGF}_{2 \alpha}$ release and reversed its stimulatory effects on $\mathrm{P}_{4}$ and $\mathrm{PGE}_{2}$ release on inhibitory. This corespond the hypothesis, that IGF-I affects these hormones through inhibition of $\mathrm{p} 21$.

Therefore, our observations did not provide conclusive evidence, that IGF-I affect ovarian secretory activity through either promotion or suppression of p21. To confirm the role of p21 as mediator of IGF-I action in control of secretory activity in porcine ovary, it should be demonstrated, that IGF-I affects accumulation or activation of p21, and that p21 blockade influences IGF-I-stimulated functions.

\section{Taken together, our observations}

1. demonstrate for a first time the involvement of p21 in stimulation of $\mathrm{P}_{4}$, OT and PGE release, but not in IGF-I and PGF release by porcine granulosa cells,

2. confirm the role of FSH in promotion of IGF-I, $\mathrm{P}_{4}$ release and the role of IGF-I in up-regulation of OT, $\mathrm{P}_{4}$ and $\mathrm{PGE}_{2}$ release and in down-regulation of $\mathrm{PGF}_{2 \alpha}$ release by porcine ovarian cells,

3. Suggest, that p21 is probably not a mediator of FSH action on porcine ovarian $\mathrm{P}_{4}$ and IGF-I; the involvement of p21 in mediating IGF-I action on some porcine ovarian hormones is not to be excluded, but it requires further confirmation.

\section{Acknowledgements}

The authors express their gratitude to Ing. Kuklová, Ms. Tóthová (Research Centre of Animal Production, Nitra, Slovakia) and Ing.Ondriska (Institute of Animal Reproduction and Food Research, Olsztyn-Kortowo, Poland) for skilful help in analysing the samples, Dr. N.D.Perkins and Dr. C.Duckett (University of Dundee, Dundee, UK) for kind providing the constructs. These studies were supported by Ministry of Education of The Slovak Republic (grant VEGA 1/35/41/06) and by Ministry of Agriculture of Slovak Republic (project RUVV 07-13).

\section{References}

1. Ball KL1997 p21: structure and functions associated with cyclin-CDK binding. Prog Cell Cycle Res 3: 125-134.

2. Harper JW, Elledge SJ, Keyomarsi K, Dynlacht B, Tsai LH, et al. (1995) Inhibition of cyclin dependent kinases by p21. Mol Biol Cell 6: 387-400.

3. El-Deiry WS, Tokino T, Velculescu VE, Levy DB, Parsons R, et al. (1993) WAF1, a potential mediator of p53 tumor suppression. Cell 75: 817-825.

4. Zhou BP, Liao Y, Xia W, Spohn B, Lee MH, et al. (2001) Cytoplasmic localization of $\mathrm{p} 21 \mathrm{Cip} 1 /$ Waf1 by Akt-induced phosphorylation in HER-2/neu-overexpressing cells. Nat Cell Biol 3: 245-252.

5. Lai A, Sarcevic B, Prall OWJ, Sutherland RL (2001) Insulin/IGFI and Estrogen Cooperate to Stimulate Cyclin ECdk2 Activation and Cell Cycle Progression in MCF7 Breast Cancer Cells Through Differential Regulation of Cyclin E and p21WAF1/Cip1. J Biol Chem 276: 25823-25833.

6. Sugibayashi R, Kiguchi Y, Shimizu T, Suzuki T, Hamada H, et al. (2002) Upregulation of $\mathrm{p} 21$ (WAF1/CIP1) levels leads to growth suppression of prostate cancer cell lines. Anticancer Res 22: 713-719.

7. Dong Y, Chi SL, Borowsky AD, Fan Y, Weiss RH (2004) Cytosolic p21Waf1/ Cip1 increases cell cycle transit in vascular smooth muscle cells. Cell Signal 16: $263-269$
8. Griffin SV, Shankland SJ (2004) Not just an inhibitor: A role for p21 beyond the cell cycle-"The truth is rarely pure and never simple". J Am Soc Nephrol 15: 825-826.

9. Dash BC, El-Deiry WS (2005) Phosphorylation of p21 in G2/M promotes cyclin B-Cdc2 kinase activity. Mol Cell Biol 25: 3364-3387.

10. Missero C, Calautti E, Eckner R, Chin J, Tsai LH, et al. (1995) Involvement of the cell-cycle inhibitor CIP1/WAF1 and the E1A-associated p300 protein in terminal differentiation. Proc Natl Acad Sci U S A 92: 5451-5455.

11. Yamamoto H, Soh JW, Shirin H, Xing WQ, Lim JT, et al. (1998) Comparative effects of overexpression of p27Kip1 and p21Cip1/Waf1 on growth and differentiation in human colon carcinoma cells. Oncogene 18: 103-115.

12. Baccini V, Roy L, Vitrat N, Chagraoui H, Sabri S, et al. (2001) Role of p21Cip1 Waf1 in cell-cycle exit of endomitotic megakaryocytes. Blood 98: 3274-3284.

13. Kramer JL, Baltathakis I, Alcantara OS, Boldt DH (2002) Differentiation of functional dendritic cells and macrophages from human peripheral blood monocyte precursors is dependent on expression of p21 (WAF1/CIP1) and required iron. $\mathrm{Br} \mathrm{J}$ Haematol 117: 727-734.

14. Devgan V, Nguyen B-C, Oh H, Dottop GP (2006) 21WAF1/Cip1 Suppresses Keratinocyte Differentiation Independently of the Cell Cycle through Transcriptional Up-regulation of the IGF-I Gene. J Biol Chem 281: 3046330470.

15. Suzuki A, Tsutomi Y, Akahane K, Araki T, Miura M (1998) Resistance to Fasmediated apoptosis: activation of caspase 3 is regulated by cell cycle regulator p21WAF1 and IAP gene family ILP. Oncogene 17: 931-939.

16. Asada M, Yamada T, Ichijo H, Delia D, Miyazono K, et al. (1999) Apoptosis inhibitory activity of cytoplasmic p21 (Cip1/ Waf1) in monocytic differentiation. EMBO J 18: 1223-1234.

17. Lawlor MA, Rotwein P (2000) Insulin-Like Growth Factor-Mediated Muscle Cel Survival: Central Roles for Akt and Cyclin-Dependent Kinase Inhibitor p21. Mo Cell Biol 20: 8983-8995.

18. Lee CJ, Kim HT, Song KW, Kim SS, Park HH, et al. (2007) Ovarian expression of p53 and p21 apoptosis regulators in $\mathrm{y}$-irradiated mice. Mol Reprod Dev 75 383-391.

19. Jirawatnotai S, Moons DS, Stocco CO, Franks R, Hales DB, et al. (2003) The cyclin-dependent kinase inhibitors p27Kip1 and p21Cip1 cooperate to restrict proliferative life span in differentiating ovarian cells. Biol Chem 278: 17021 17027.

20. Wright JW, Stouffer RL, Rodland KD (2005) High-Dose Estrogen and Clinical Selective Estrogen Receptor Modulators Induce Growth Arrest, p21, and p53 in Primate Ovarian Surface Epithelial Cells. J Clin Endocrinol Metab 90: 36883695.

21. Lukas J, Groshen S, Saffari B, Niu N, Reles A, et al. (1997) WAF1/Cip1 gene polymorphism and expression in carcinomas of the breast, ovary, and endometrium. Am J Pathol 150: 167-175.

22. Barboule N, Baldin V, JOzan S, Vidal S, Valette A (1998) Increased level of p21 in human ovarian tumors is associated with increased expression of cdk2 cyclin A and PCNA. Int J Cancer 76: 891-896.

23. Piek JM, Verheijen RH, Menko FH, Jongsma AP, Weegenaar J, et al. (2003) Expression of differentiation and proliferation related proteins in epithelium of prophylactically removed ovaries from women with a hereditary female adnexal cancer predisposition. Histopathology 43: 26-32.

24. Giudice LC (1992) Insulin-like growth factors and ovarian follicular development Endocr Rev 13: 641-669.

25. Kolodziejczyk J, Gertler A, Leibovich H, Rzasa J, Gregoraszczuk EL (2002) Synergistic action of growth hormone and insulin-like growth factor I (IGF-I) on proliferation and estradiol secretion in porcine granulosa and theca cells cultured alone or in coculture. Theriogenology 60: 559-570.

26. Zeleznik AJ (2004) Dynamics of primate follicular growth: a physiologica perspective. In: The Ovary, second edition. Leung, P.C.K. and Adashi, E.Y. (Editors), Elsevier Academic Press. Salt Lake City, Utah, USA, 45-52.

27. Cao Z, Liu LZ, Dixon DA, Zheng JZ, Chandran B, et al. (2007) Insulin-like growth factor-I induces cyclooxygenase-2 expression via PI3K, MAPK and PKC signaling pathways in human ovarian cancer cells. Cell Signal. 19: 15421553. 
Citation: Pavlová S, Vašíček D, Kotwica J, Sirotkin AV (2010) Involvement of Cell Cycle and Apoptosis-Related Protein p21 in Control of Secretory Activity of Porcine Ovarian Cells. J Steroids Hormon Sci 1:102. doi:10.4172/2157-7536.1000102

Page 5 of 5

28. Kwintkiewicz J, Giudice LC (2009) The interplay of insulin-like growth factors, gonadotropins, and endocrine disruptors in ovarian follicular development and function. Semin Reprod Med 27: 43-51.

29. Dupont J, Le Roith D (2001) Insulin-like growth factor 1 and oestradiol promote cell proliferation of MCF-7 breast cancer cells: new insights into their synergistic effects. Mol Pathol 54: 149-154.

30. Sirotkin AV (1996) Direct action of growth hormone on bovine ovarian cells: effects on estradiol, oxytocin, vasopressin secretion by granulosa cells and on oocyte maturation and cleavage in vitro. Ann Endocrinol (Paris) 57: 219-224.

31. Sirotkin AV, Makarevich AV (1999) GH regulates secretory activity and apoptosis in cultured bovine granulosa cells through the activation of the cAMP/ protein kinase A system. J Endocrinol 163: 317-327.

32. Mészárosová M, Sirotkin AV, Grossmann R, Darlak K, Valenzuela F (2008) The effect of obestatin on porcine ovarian granulosa cells. Anim Reprod Sci. 108 196-207.

33. Perkins ND, Felzien LK, Betts JC, Leung K, Beach DH, et al. (1997) Regulation of NF-kB by Cyclin-Dependent Kinases Associated with the p300 Coactivator. Science $275,523-527$

34. Kotwica J, Skarzynski D (1993) Influence of oxytocin removal from corpus luteum on secretory function and duration of estrous cycle in cattle. J Reprod Fertil 97: 411-417.

35. Hatey F, Langlois I, Mulsant P, Bonnet A, Benne F, et al. (1992) Gonadotropins induce accumulation of insulin-like growth factor I mRNA in pig granulosa cells in vitro. Mol Cell Endocrinol 82: 205-211.

36. LaBarbera AR, Ryan RJ (1981) Porcine granulosa cells in suspension culture. II. Luteinization and hCG responsiveness. Am J Physiol 240: 622-629.

37. Sirotkin AV, Makarevich AV, Kotwica J, Marnet PG, Kwon HB, et al. (1998) Isolated porcine ovarian follicles as a model for the study of hormone and growth factor action on ovarian secretory activity. J Endocrinol 159: 313-321.

38. Chaffin CL, Schwinof KM, Stouffer RL (2001) Gonadotropin and steroid contro of granulosa cell proliferation during the periovulatory interval in Rhesus Monkeys. Biol Reprod 65, 755-762.

39. Stormshak F (2003) Biochemical and endocrine aspects of oxytocin production by the mammalian corpus luteum. Reprod Biol Endocrinol 1: 92.

40. Yadav VK, Lakshmi G, Medhamurthy R (2005) Prostaglandin F2alphamediated activation of apoptotic signaling cascades in the corpus luteum during apoptosis: Involvement of caspase activated Dnase. J. Biol Chem 280: 1035710367.

41. Franczak A, Kurowicka B, Oponowicz A, Petroff BK, Kotwica G (2006) The effect of progesterone on oxytocin-stimulated intracellular mobilization of
Ca2+ and prostaglandin E2 and F2 $\alpha$ secretion from porcine myometrial cells. Prostaglandins Other Lipid Mediat 81: 37-44.

42. Shirasuna K, Shimizu T, Hayashi KG, Nagai K, Matsui M, et al. (2007) Positive Association, in Local Release, of Luteal Oxytocin with Endothelin 1 and Prostaglandin F2alpha During Spontaneous Luteolysis in the Cow: A Possible Intermediatory Role for Luteolytic Cascade Within the Corpus Luteum. Biol Reprod 76: 965-970.

43. Bogan RL, Murphy MJ, Stouffer RL, Hennebold JD (2008) Prostaglandin synthesis, metabolism, and signaling potential in the rhesus macaque corpus luteum throughout the luteal phase of the menstrual cycle. Endocrinology 149 5861-5871.

44. Rekawiecki R, Kowalik MK, Slonina D, Kotwica J (2008) Regulation of progesterone synthesis and action in bovine corpus luteum. J Physio Pharmacol 59: 75-89.

45. Waclawik A, Kaczmarek MM, Kowalczyk AE, Bogacki M, Ziecik AJ (2008) Expression of prostaglandin synthesis pathway enzymes in the porcine corpus luteum during the oestrous cycle and early pregnancy. Theriogenology 70: 145 152.

46. Tachibana T, Fujiwara H, Suginami H, Nakamura K, Honda T, et al. (1996) An aminopeptidase inhibitor, bestatin, enhances progesterone and oestradio secretion by porcine granulosa cells stimulated with follicle stimulating hormone in vitro. Hum Reprod 11: 497-502.

47. Schams D, Koll R, Li CH (1988) Insulin-like growth factor-I stimulates oxytocin and progesterone production by bovine granulosa cells in culture. J Endocrino 116: $97-100$

48. Sirotkin AV, Florkovicova I, Makarevich AV, Schaeffer HJ, Kotwica J, et al. (2003) Oxytocin mediates some effects of insulin-like growth factor-I on porcine ovarian follicles. J Reprod Dev 49: 141-149.

49. Apa R, Miceli F, Pierro E, Minici F, Navarra P, et al. (1999) Paracrine regulation of insulin-like growth factor I (IGF-I) an IGF-II on prostaglandins F2alpha and E2 synthesis by human corpus luteum in vitro: a possible balance of luteotropic and luteolytic effects. J Clin Endocrinol Metab 84: 2507-2512.

50. Sirotkin AV, Rafay J, Kotwica J, Darlak K, Valenzuela F (2009) Role of ghrelin in regulating rabbit ovarian function and the response to LH and IGF-I. Domest Anim Endocrinol 36: 162-172.

51. Yuan W, Lucy MC (1996) Effects of growth hormone, prolactin, insulin-like growth factors, and gonadotropins on progesterone secretion by porcine luteal cells. J Anim Sci 74: 866-872.

52. Nishikori M (2005) Classical and alternative NF-kB Activation Pathways and their roles in lymphoid malignancies. J Clin Exp Hematopathol 45: 15-24. 